\title{
Combining Option Approach with Logistic Regression Analysis \\ to Measure Default Risk of Listed Companies on Vietnamese Stock Market
}

\author{
PHAN ĐİNH ANH \\ Đà Nẵng University of Economics \\ dinhanhdhkt@gmail.com \\ NGUYẼ̃N HÒA NHÂN \\ Đà Nẵng University of Economics \\ nhndhdn@yahoo.com
}

\begin{abstract}
ARTICLE INFO
ABSTRACT

Received:

March 12, 2013

Received in revised form May 16, 2013

Accepted:

June 15, 2013

This paper explores correlation between growth of stock market and economic growth in Vietnam by examining causal relationship between VN-Index and the GDP. The results show that there is no evidence of a causal relation between VN-Index and economic growth. This finding allows several implications of restructuring of the Vietnamese economy.
\end{abstract}

Keywords:

default risk

risk measurement

listed companies

combined model 


\section{INTRODUCTION}

Accurately measuring the default risk in an enterprise is the first criterion for any credit rating model. However, common approaches such as credit scoring or statistical methods only focus on certain financial indicators of businesses. Data on listed enterprises, however, are not frequently updated and objectively presented since their financial statements are usually publicized on a quarterly basis and generally not required to be audited by independent auditors.

In the meantime, models applying the option approach to measure default risk have overcome this shortcoming by exploiting information from the company's stock prices via the implication of Merton's option pricing model (referred to as option approach hereafter), an approach that allows default risk of a company to be updated over time, ensures objectivity based on continuity of stock prices, and acts as market evaluation of company value. Main shortcoming of the pure option approach is the use of many assumptions, which do not fit market facts, to facilitate calculations.

Hence, a research method that helps make the best use of strengths and reduce limitations of option approach is combined models that employ probit or logit regression analysis with dependent variables being binary ones for default risk of companies and independent variables being those whose values are not directly observed in the market but can be estimated from the company's stock prices by option approach (referred to "market variables" for short).

Papanastasopoulos (2006), with a sample of 410 companies listed on the U.S. and Canada stock markets during the 2002-2003 period, found that market variables explained $70 \%$ of the default risk and correctly forecasted insolvency $94.5 \%$ of surveyed firms. Charitou and Trigeorgis (2004) with a sample of 420 U.S. companies in the years 1986-2001 confirmed the important role of market variables in explaining the default risk of companies. Vassalou and Xing (2004) found support for effects of corporate size and book-to-market ratio on the default risk. Similar results from researches on Vietnamese stock markets, however, have not been recorded, so this study made use of combined models and conducted empirical research on companies listed on Vietnamese stock markets to develop the most effective model for measuring default risk among this group.

\section{MEASURING DEFAULT RISK OF LISTED COMPANIES ON VIETNAMESE STOCK MARKETS}




\section{a. Default Risk:}

Default risk is the possibility that a company cannot repay obligation on due date as promised. There exist both subjective and objective factors that result in the insolvency. The former may show themselves in business strategies and managerial competence. The latter include economic recession, macroeconomic volatility, political factors, and changes in economic policies, etc. that have huge impacts on the default risk and are often beyond the control of a business.

In the market economy default risk is an objective phenomenon, whose consequences include not only losses caused by the company for its creditors but also conflict of interests among investors, creditors, and employees; thereby disrupting the links between entities involved in economic relations and affecting the socioeconomic development of the country. Despite not being identical to bankruptcy risks, a default one can be considered as a prerequisite for bankruptcy of a business. Therefore, prompt identification and early warning of insolvency risks are essential instruments for risk management in businesses and alert signals for investors and creditors.

\section{b. Logistic Model:}

Logistic model is to study the dependence of a binary variable $\mathrm{Y}$ on other independent ones (continuous or discrete).

Because $\mathrm{Y}$ is a binary variable, it should only take two values as follows:

$$
Y_{i}=\left\{\begin{array}{l}
1: \text { if phenomenon occurs } \\
0: \text { if no phenomenon occurs }
\end{array}\right.
$$

$p_{i}=p\left(Y_{i}=1 / X_{i}\right)$ is a probability that $Y_{i}=1$, i.e. the probability in which the phenomenon occurs when an independent variable has the value $X_{i}$. Because $p_{i}$ is a probability, $0 \leq \mathrm{p}_{\mathrm{i}} \leq 1 \forall \mathrm{i}$; this is the basic hypothesis of the logistic regression model. According to the theory of logistic regression, the probability $\mathrm{p}_{\mathrm{i}}$ is determined by the following formula:

$$
p_{i}=p\left(Y_{i}=1\right)=\frac{\exp \left(\beta_{0}+\beta_{1} X_{1 i}+\beta_{2} X_{2 i}+\ldots+\beta_{k} X_{k i}\right)}{1+\exp \left(\beta_{0}+\beta_{1} X_{1 i}+\beta_{2} X_{2 i}+\ldots+\beta_{k} X_{k i}\right)}
$$


From (1.1), when $X_{i}$ changes from $-\infty \rightarrow+\infty, p_{i}$ only accepts the value ranging from 0 to 1 , satisfying basic hypothesis of the model. By creating $z=\beta_{0}+\beta_{1} X_{1 i}+\beta_{2} X_{2 i}+\ldots .+$ $\beta_{\mathrm{k}} \mathrm{X}_{\mathrm{ki}}$ we can rewrite (1.1) with $\mathrm{z}$ included.

$$
\begin{aligned}
& p_{i}=p\left(Y_{i}=1\right)=\frac{e^{z}}{1+\mathrm{e}^{\mathrm{z}}} \text { and } 1-p_{i}=p\left(Y_{i}=0\right)=\frac{1}{1+\mathrm{e}^{\mathrm{z}}} \\
& \Rightarrow \ln \left[\frac{p_{i}}{1-p_{i}}\right]=\beta_{0}+\beta_{1} X_{1 i}+\beta_{2} X_{2 i}+\ldots+\beta_{k} X_{k i}
\end{aligned}
$$

This is a form of multivariate model of logistic regression. To estimate $\beta_{\mathrm{i}}$ we can use such software as SPSS and EViews, etc.

\section{c. Default Risk Measurement Model Based on Option Pricing Theory:}

- Default probability:

Let $\mathrm{PD}_{\mathrm{T}}$ be default probability of a business at time $\mathrm{T}$ in the future observed at the present time, $V_{A}^{T}$ market value of corporate total assets at time $\mathrm{T}$, and $\mathrm{D}_{\mathrm{T}}$ a default threshold at time $\mathrm{T}$. Then at time of observation, the default risk at time $\mathrm{T}$ in the future is measured as $\mathrm{PD}_{\mathrm{T}}=\mathrm{p}\left(V_{A}^{T}<\mathrm{D}_{\mathrm{T}}\right)=\mathrm{p}\left(\ln V_{A}^{T}<\ln \mathrm{D}_{\mathrm{T}}\right)$

Assume that $V_{A}^{T}$ satisfies the following stochastic differential equation:

$$
d V_{A}=\mu_{A} V_{A} d t+\sigma_{A} V_{A} d z
$$

where $\mu_{A}$ is expected return of total assets, $\sigma_{A}$ is volatility of market value of corporate assets, and $\mathrm{dz}$ is Wiener process.

This assumption allows the expression of corporate total assets over time:

$$
\ln V_{A}^{t}=\ln V_{A}^{0}+\left(\mu_{A}-\sigma_{A}^{2} / 2\right) t+\sigma_{\mathrm{A}} \sqrt{t} \varepsilon
$$

with $\varepsilon$ as a random element of return from total assets.

By applying (2.2) and recalculating (2.1), default probability is identified from cumulative standardized normal distribution function $\mathrm{N}(\mathrm{x})$ : 


$$
P D_{T}=N\left[-\frac{\ln \frac{V_{A}^{0}}{D_{T}}+\left(\mu_{A}-\frac{\sigma_{A}^{2}}{2}\right) T}{\sigma_{A} \sqrt{T}}\right]=N(-D D)
$$

where $D D=\frac{\ln \frac{V_{A}^{0}}{D_{T}}+\left(\mu_{A}-\frac{\sigma_{A}^{2}}{2}\right) T}{\sigma_{A} \sqrt{T}}$ is called distance to default by $\mathrm{KMV}^{[1]}$, that is, the distance from asset value to default threshold is measured by fluctuations in market value of assets.

- Calculation of distance to default

To calculate distance to default, it is necessary to identify such parameters: (1) observing time (an assigned parameter); (2) default threshold (identified from financial statements of business); (3) present market value of assets; (4) expected return of assets; and (5) volatility of market value of assets (all are measured via stock price, following the option approach of Merton's stock pricing model.

According to this approach, the capital structure of a company includes ordinary share capital and debt capital in which the market value of share capital is value of a call option over market value of corporate assets, and realized price is face value of all debts of a company at due date.

Let $E^{0}$ be market value of share capital and $V_{A}^{0}$ present asset value; $E^{T}$ and $V_{A}^{T}$ are these values at $T$, the due date of debts if $X$ is the face value of all debts at due date, the market value of share capital at due date $\mathrm{T}$ is $E^{T}=\operatorname{Max}\left(0, V_{A}^{T}-X\right)$.

By adopting hypotheses appropriate to the option pricing theory, $E^{0}$ or value of call option can be identified by the formula introduced by Black and Scholes (1973):

$$
\begin{aligned}
E^{0} & =V_{A}^{0} N\left(d_{1}\right)-X e^{-r T} N\left(d_{2}\right) \\
d_{1} & =\frac{\ln \frac{V_{A}^{0}}{X}+\left(r+\frac{\sigma_{A}^{2}}{2}\right) T}{\sigma_{A} \sqrt{T}} ; d_{2}=d_{1}-\sigma_{A} \sqrt{T}
\end{aligned}
$$

where $r$ is risk-free interest rate. 
To estimate the parameters (3), (4) and (5), volatility of market value of share capital should initially be described, applying stochastic differential equation

$$
d E=\mu_{E} E d t+\sigma_{\mathrm{E}} E d z
$$

$\mu_{E}$ is expected return of share capital and $\sigma_{E}$ is volatility of market value.

From (2.4), share value is a function of two variables - asset value and time. By the application of Ito formula, the differential equation of market value of share capital expressed in those two variables can be rewritten as:

$$
\begin{aligned}
d E & =\frac{\partial E}{\partial V_{A}} d V_{A}+\frac{\partial E}{\partial t} d t+\frac{1}{2} \sigma_{E}^{2} V_{A}^{2} \frac{\partial^{2} E}{\partial V_{A}^{2}}\left(d V_{A}\right)^{2} \ldots \\
& =\left(\frac{1}{2} \sigma_{A}^{2} V_{A}^{2} \frac{\partial^{2} E}{\partial V_{A}^{2}}+\mu_{A} V_{A} \frac{\partial E}{\partial V_{A}}+\frac{\partial E}{\partial t}\right) d t+\sigma_{A} V_{A} \frac{\partial E}{\partial V_{A}} d z
\end{aligned}
$$

Identifying (2.5) with (2.6), we have:

$$
\begin{aligned}
& \sigma_{\mathrm{E}} E=\sigma_{A} V_{A} \frac{\partial E}{\partial V_{A}} \text { and } \mu_{E} E=\frac{1}{2} \sigma_{A}^{2} V_{A}^{2} \frac{\partial^{2} E}{\partial V_{A}^{2}}+\mu_{A} V_{A} \frac{\partial E}{\partial V_{A}}+\frac{\partial E}{\partial t} \\
& \frac{\partial E}{\partial V_{A}} ; \frac{\partial^{2} E}{\partial V_{A}^{2}} ; \frac{\partial E}{\partial t} \text { in (2.7) and (2.8) are delta, gamma, and theta option respectively }
\end{aligned}
$$

and they can be directly calculated from (2.4).

$$
\begin{aligned}
& \text { delta }=\Delta^{E}=\frac{\partial E}{\partial V_{A}}=N\left(d_{1}\right), \text { gamma }=\Gamma^{E}=\frac{\partial^{2} E}{\partial V_{A}^{2}}=\frac{n\left(d_{1}\right)}{V_{A} \sigma_{A} \sqrt{T}} \\
& \text { theta }=\theta^{E}=\frac{\partial E}{\partial t}=-\frac{V_{A} n\left(d_{1}\right) \sigma_{A}}{2 \sqrt{T}}-r X e^{-r T} N\left(d_{2}\right)
\end{aligned}
$$

where $\mathrm{n}(\mathrm{x})$ is density function of standardized normal distribution

The market value of share capital can be directly observed in the stock market. Volatility of such values can be measured by referring to past volatility. Thus, after identifying such parameters as risk-free interest rate, maturity date of debts and face value of company debts, we should solve (2.4) and (2.7) to detect two unknown variables - asset market value and volatility of asset value. Finally, the expected return from assets 
is directly calculated with (2.8) after the expected return of share capital from stock price is identified.

\section{d. Combining Logistic Regression Analysis and Option Approach to Measure Default Risk:}

Should they be based on the hypotheses of Merton's model, default probabilities can be calculated directly with N(-DD ). However, the problem here is that the accuracy of this probability depends crucially on the initial assumptions that may not fit the reality. However, the option approach helps identify the variables affecting default risk, indicates the trends of influence from variables and methodology of estimation of values of these variables from the market value of share capital. Combined with the advantages of logistic regression analysis which allows estimation of probability based on realities, the combined model using logistic regression analysis has the binary variable reflecting default risk as its dependent variable and variables identified in the default risk measuring model following the option approach as its independent ones.

From (2.3) we can identify five variables to be used for calculating the distance to default. Derivative of the probability function $\mathrm{PD}_{\mathrm{T}}$ with respect to those variables shows that the default risk has negative relationships with market value of assets and expected return of assets and positive relationship with default threshold and volatility of market value of assets. In other words, if the ratio $\mathrm{D}_{\mathrm{T}} / V_{A}^{0}$ is used to represent market gearing ratio of the company, default risk is positively related to the market gearing ratio and volatility of asset market value, and negatively related to expected return of the assets.

\section{A DEFAULT RISK MEASURING MODEL FOR LISTED COMPANIES ON VIETNAMESE STOCK MARKETS}

\section{a. Research Design:}

- Companies facing default risk:

In this research, the authors used the definition of businesses exposed to default risk based on indicators of default risk according to Basel II ${ }^{[2]}$ standards whereby a business is exposed to default risk when at least one of the following incidents occur:
A. The business shows its inability to fulfill credit obligation to its partners
B. Its permanent working capital is frequently smaller than zero
C. The market value of the business is smaller than total payable 
Table 1: Signs of Default Risk

\begin{tabular}{cll}
\hline Sign & \multicolumn{1}{c}{ Indicator } & \multicolumn{1}{c}{ How to identify } \\
\hline \multirow{2}{*}{ A } & Overdue debt & $\begin{array}{l}\text { Having overdue debts and/or being required to pay } \\
\text { debts by creditors due to failure to make repayment of } \\
\text { debts when due. }\end{array}$ \\
B & Permanent working capital & Total short-term asset - Total short-tem debt \\
C & Market value of company & Price of one share x volume of outstanding shares \\
\cline { 2 - 3 } & Total payable & Short-term debt + long-term debt \\
\hline
\end{tabular}

Source: Authors' calculations

- Selection of variables:

To apply logistic regression analysis, dependent and independent variables in the model should be identified.

+ Dependent variables: The research makes use of dependent variable Y which is a binary one with two values:

$$
Y=\left\{\begin{array}{l}
1 \text { if company faces default risk } \\
0 \text { if the company does not }
\end{array}\right.
$$

+ Independent variables: Selected independent variables are those that influence on default risk and in this research they are divided into two groups:

- Group 1 is composed of several financial ratios collected from financial statements of companies.

- Group 2 comprises four identified market variables whose values are estimated by the option approach and presented in Table 4.

\section{b. Data, Data Processing and Sampling:}

- Data:

Data about companies listed on HOSE and HNX in 2010-2011 were collected from various websites. These include :

+ Closing price of trading days from Jan 1, 2010 to Dec 31, 2011

+ Volume of outstanding stocks from Dec 31, 2010 and Dec 31, 2011

+ Audited financial statements publicized at the end of 2010 and 2011 
+ Interest rate of 2-year government bonds at the end of 2010 and 2011

+ Information regarding the borrowing and repayment of companies

- Sample description:

The surveyed companies are non-financial ones, i.e. companies that do not operate in banking, insurance, securities brokerage, and financial leasing sectors. Two selected samples include:

+ Sample 1: is used to perform logistic regression analysis and modeling and composed of 290 companies, including 144 at default risk, accounting for $49.6 \%$ of the total and 146 companies not exposed to default risk, counting 50.4\%, which is based on the signs of default risk defined in Table 1 , and the period to determine the status of default risk is late 2010 .

+ Sample 2 consists of 170 companies, including 126 at default risk, counting $74.1 \%$ and 44 without the risk of default, counting $25.9 \%$, and the period is late 2011 when Vietnamese stock market reached its lowest level of the year, causing a significant increase in the number of surveyed companies exposed to default risk as compared with 2010. This sample is also used to test predictability and stability of the models constructed from Sample 1.

Table 2: Sample Description

\begin{tabular}{cccccccc}
\hline & & \multicolumn{3}{c}{ Sample 1 } & \multicolumn{3}{c}{ Sample 2 } \\
\cline { 3 - 8 } No. & $\begin{array}{c}\text { Indicators of } \\
\text { default risk }\end{array}$ & $\begin{array}{c}\text { Companies } \\
\text { with } \\
\text { default } \\
\text { risk }\end{array}$ & $\begin{array}{c}\text { Companies } \\
\text { without } \\
\text { default } \\
\text { risk }\end{array}$ & $\begin{array}{c}\text { Size } \\
\text { with } \\
\text { default } \\
\text { risk }\end{array}$ & $\begin{array}{c}\text { Companies } \\
\text { without } \\
\text { default } \\
\text { risk }\end{array}$ & Size \\
\hline 1 & A & 10 & 280 & 7 & 163 & \\
2 & B & 58 & 232 & 290 & 37 & 133 & 170 \\
3 & C & 126 & 164 & & 126 & 44 & \\
4 & A +B+C & 144 & 146 & 126 & 44 & \\
\hline
\end{tabular}

Source: Authors' calculations

- Data processing method: 
For the independent variables of Group 1, over 30 financial indicators ${ }^{[3]}$ were collected from the financial statements for the years 2010 and 2011 of the companies listed on HOSE and HNX.

To determine the values of the independent variables of Group 2 from the stock prices, data is processed as follows:

+ Identify the input parameters:

Maturity date of debts (T) based on due dates for repayment is complicated and not easily accessible; therefore, in the research, the debts are assumed to be due after one year since consideration and therefore $\mathrm{T}=1$.

Face value of all debts $(\mathrm{X})$ represents the default threshold in Merton's model. In reality, a company can continue its operation even if its assets are smaller than the total debt provided that these debts are not due to be repaid. For such reason, if the total debt is used to represent the default threshold, there would be certain errors because not all of the debts are to be due in one year. On the contrary, using only short-term debts will not fully reflect the problem because in case of the companies being on the brink of bankruptcy when they are incapable of paying the due short-term debts, creditors have the right to demand repayment of long-term debts, despite not being due. Findings from researches by Crosbie and Bohn (2003) and Vassalou and Xing (2004) allow the authors to use the total value of short-term debts and half of the value of long-term debts from financial statements to represent the face value of all debts or:

$\mathrm{X}=$ short-term debts $+0.5 *$ long-term debts.

Market value of share capital $\left(\mathrm{E}^{0}\right)=$ volume of outstanding stocks $*$ closing price of one stock

Risk-free interest rate (r): interest rate of 2-year government bonds.

Expected return of share capital $\left(\mu_{E}\right): \mu_{E}=252 \bar{\mu}_{E}$

Volatility of share capital $\sigma_{E}=\sqrt{252} \sqrt{\frac{1}{n-1} \sum_{i=1}^{n}\left(\mu_{E}^{i}-\bar{\mu}_{E}\right)^{2}}$

( $\mathrm{n}$ is defined as 253 days and , $\mu_{E}^{i}=\ln \left(\mathrm{P}_{\mathrm{i}} / \mathrm{P}_{\mathrm{i}-1}\right)$ in which $\mathrm{P}_{\mathrm{i}}$ is closing price of the stock of trading day $i$ in the fiscal year and $\bar{\mu}_{E}=\frac{1}{n} \sum_{i=1}^{n} \mu_{E}^{i}$ ) 
+ Determine the present market value of assets $\left(V_{A}^{0}\right)$ and volatility of asset value $\left(\sigma_{A}\right)$ :

This is done by solving the equation system (2.4) and (2.7). To find the results, the authors used iteration and the calculation was done quickly on Excel spreadsheets by performing the following sequence:

Step 1: Choose an initial value of the market value and volatility of the asset value. Use these two factors to determine a new value of the asset value from the equation $V_{A}^{0}=\frac{E^{0}+X e^{-r} N\left(d_{2}\right)}{N\left(d_{1}\right)}$. Insert the new value of the asset into the right hand side of the equation to get another new value of assets and continue this process until the new one is equal to the one previously inserted.

Step 2: Apply the value achieved in Step 1 and the initially chosen value of volatility to do a rapid calculation of that volatility, following the formula $\sigma_{A}=\frac{E^{0} \sigma_{E}}{V_{A}^{0} N\left(d_{1}\right)}$

Step 3: Use the values achieved in both Step 1 and Step 2 to repeat the two steps. This repetition process will end when the new values are to be equal to the previous ones.

+ Determine the expected return by applying (2.8)

$$
\mu_{A}=\frac{\mu_{E} E^{0}-\theta^{E}-\frac{1}{2} \sigma_{A}^{2}\left(V_{A}^{0}\right)^{2} \Gamma^{E}}{V_{A}^{0} \Delta^{E}}
$$

\section{RESULTS AND DISCUSSIONS}

\section{a. Results:}

Regression analysis is performed for each group of independent variables.

As for Group 1, initial variables of financial indicators will be tested and selected, and only those that most effectively explain default status will be maintained. Finally, Model 1 with four independent variables defined in Table 3 is chosen. 
Table 3: Definition of Financial Indicators as Variables

\begin{tabular}{lllcc}
\hline $\begin{array}{c}\text { Indicator } \\
\text { Group }\end{array}$ & \multicolumn{1}{c}{ Indicator } & \multicolumn{1}{c}{ Formula } & Symbol & $\begin{array}{c}\text { Expected } \\
\text { sign }\end{array}$ \\
\hline Leverage & Gearing Ratio & Total debt/ Total Asset & Ts_No & + \\
Performance & Return on Equity & After-Tax Profit/ & ROE & - \\
& & Shareholder's equity & & \\
& Return on Sales & After-tax profit/Sales & Ts_LNDT & - \\
Operation & Asset Turnover Ratio & Sales /Total Asset & Hs & - \\
\hline
\end{tabular}

Note: +/-: Positive/negative impact on default risk

Source: Authors' calculations

As for market variables, the regression analysis is performed with four independent variables defined in Table 4. Model 2 is selected after the regression analysis is performed with three independent variables TsNo_TT, DBD_TS, and LT_TS and the variable DBD_TS is eliminated after a test on irrelevant variables. Model 3 is obtained after a simple regression is performed with the variable "distance to default."

Table 4: Definition of Market Variables

\begin{tabular}{cccc}
\hline $\begin{array}{c}\text { Variable } \\
\text { Symbol }\end{array}$ & Variable & Formula & Expected sign \\
\hline TsNo_TT & Market gearing ratio & $\mathrm{X} / V_{A}^{0}$ & + \\
DBD_TS & Volatility of asset value & $\sigma \mathrm{A}$ & + \\
LT_TS & Expected return of assets & $\mu \mathrm{A}$ & - \\
DD & Distance to default & $\frac{\ln \frac{V_{A}^{0}}{X}+\left(\mu_{A}-\frac{\sigma_{A}^{2}}{2}\right)}{\sigma_{A}}$ \\
\hline
\end{tabular}

+/-: Positive/negative impact on default risk

Source: Authors' calculations 
b. Discussion:

Table 5: Results of Three Regression Models

\begin{tabular}{|c|c|c|c|}
\hline Variable & Model 1 & Model 2 & Model 3 \\
\hline Constant & $\begin{array}{l}-8.3477 * \\
(-5.5885)\end{array}$ & $\begin{array}{l}-25.4570 * \\
(-4.5509)\end{array}$ & $\begin{array}{l}6.5267 * \\
(7.8248)\end{array}$ \\
\hline Ts_No & $\begin{array}{c}22.7651 * \\
(6.9137)\end{array}$ & & \\
\hline ROE & $\begin{array}{c}-13.0182 * \\
(-3.5489)\end{array}$ & & \\
\hline Ts_LNDT & $\begin{array}{c}-6.6533 * * \\
(-1.9949)\end{array}$ & & \\
\hline Hs & $\begin{array}{c}-0.6349 * * \\
(-1.9831)\end{array}$ & & \\
\hline LT_TS & & $\begin{array}{c}-7.6733 * * \\
(-1.9805)\end{array}$ & \\
\hline TsNo_TT & & $\begin{array}{l}52.011 * \\
(4.7316)\end{array}$ & \\
\hline $\mathrm{DD}$ & & & $\begin{array}{l}-8.1435^{*} \\
(7.8248)\end{array}$ \\
\hline Obs. (N) & 290 & 290 & 290 \\
\hline Log likelihood & -53.353 & -19.924 & -71.650 \\
\hline McFadden R-squared & 0.734 & 0.901 & 0.643 \\
\hline Akaike info criterion & 0.402 & 0.158 & 0.507 \\
\hline Schwarz criterion & 0.465 & 0.196 & 0.533 \\
\hline Hannan-Quynn criterion & 0.427 & 0.173 & 0.518 \\
\hline Value of model test & 0.000 & 0.000 & 0.000 \\
\hline
\end{tabular}

Note: * : significant at $1 \%$; **: significant at $5 \%$

Source: Authors' calculations 
- Results of default-risk regression models with variables of financial indicators are presented in column 2 of Table 5 (Model 1) and four financial indicators used as explanatory variables are gearing ratio, return on equity, return on sales, and asset turnover ratio. All these variables are statistically significant at 5\%, and signs of coefficients match the expectations. Gearing ratio with a positive regression coefficient shows that this one has a positive relationship with the default risk, and the remaining explanatory variables having negative coefficients imply that return on equity, return on sales, and asset turnover ratio have negative relationships with default risk. Furthermore, the coefficient of determination (McFadden R-squared) of the model being 0.734 suggests that the financial indicators included in the model can successfully explain $73.4 \%$ of volatility of default risk.

- Column 3 of Table 5 demonstrates the results of default-risk regression model using market variables (Model 2) with two explanatory variables being market gearing ratio and expected return of assets. The former is statistically significant at $1 \%$, whereas the latter at 5\%. Signs of regression coefficients of these two variables also match the expectations. The positive sign of market gearing ratio implies that this variable is positively related to default risk, while expected return of assets is negatively related to default risk because its regression coefficient bears a negative sign. Moreover, the coefficient of determination of the model being 0.901 suggests that $90.1 \%$ of changes in default risk could be explained by the two variables.

Column 4 of Table 5 displays results of default-risk regression model using distance to default (Model 3). Despite its statistical significance at $1 \%$ and sign of its regression coefficient compliant with expectations, the variable "distance to default" can only explain $64.3 \%$ of changes in default risk. Moreover, the values of Akaike, Schwarz, and Hannan-Quynn criteria in Model 3 are all higher than those in Model 2; therefore, in terms of market variables, the distance to default as a variable cannot explain the default risk better than component variables used for calculating the distance to default.

The coefficient of determination of Model 2 is greater than that of Model 1 while the information criteria are lower, and thus the use of information extracted from stock prices allows better improvement in interpretation of default risk than financial indicators of the company. 
Table 6: Predictability of Default Risk of the Models for Sample 1

\begin{tabular}{|c|c|c|c|c|c|c|c|c|c|c|}
\hline \multirow{3}{*}{ Model } & \multicolumn{4}{|c|}{ Companies with risk (144) } & \multicolumn{4}{|c|}{ Companies without risk (146) } & \multirow{2}{*}{\multicolumn{2}{|c|}{$\begin{array}{c}\text { Total (290) } \\
\text { Accurate }\end{array}$}} \\
\hline & \multicolumn{2}{|c|}{ Accurate } & \multicolumn{2}{|c|}{ Inaccurate } & \multicolumn{2}{|c|}{ Accurate } & \multicolumn{2}{|c|}{ Inaccurate } & & \\
\hline & Number & $\begin{array}{l}\text { As } \\
\%\end{array}$ & Number & $\begin{array}{c}\text { As } \\
\%\end{array}$ & Number & $\begin{array}{c}\text { As } \\
\%\end{array}$ & Number & $\begin{array}{l}\text { As } \\
\%\end{array}$ & Number & $\begin{array}{l}\text { As } \\
\%\end{array}$ \\
\hline 1 & 131 & 90.97 & 13 & 9.03 & 135 & 92.47 & 11 & 7.53 & 266 & 91.72 \\
\hline 2 & 141 & 97.92 & 3 & 2.08 & 142 & 97.26 & 4 & 2.74 & 283 & 97.59 \\
\hline
\end{tabular}

Source: Results of data processing with Eviews

Table 7: Predictability of Default Risk of the Models for Sample 2

\begin{tabular}{|c|c|c|c|c|c|c|c|c|c|c|}
\hline \multirow{3}{*}{ Model } & \multicolumn{4}{|c|}{ Companies with risk (126) } & \multicolumn{4}{|c|}{ Companies without risk (44) } & \multirow{2}{*}{\multicolumn{2}{|c|}{$\begin{array}{c}\text { Total (170) } \\
\text { Accurate }\end{array}$}} \\
\hline & \multicolumn{2}{|c|}{ Accurate } & \multicolumn{2}{|c|}{ Inaccurate } & \multicolumn{2}{|c|}{ Accurate } & \multicolumn{2}{|c|}{ Inaccurate } & & \\
\hline & Number & $\begin{array}{l}\text { As } \\
\%\end{array}$ & Number & $\begin{array}{l}\text { As } \\
\%\end{array}$ & Number & $\begin{array}{l}\text { As } \\
\%\end{array}$ & Number & $\begin{array}{l}\text { As } \\
\%\end{array}$ & Number & $\begin{array}{l}\text { As } \\
\%\end{array}$ \\
\hline 1 & 118 & 93.65 & 8 & 6.35 & 37 & 84.09 & 7 & 15.91 & 155 & 91.18 \\
\hline 2 & 125 & 99.21 & 1 & 0.79 & 43 & 97.73 & 1 & 2.27 & 168 & 98.82 \\
\hline
\end{tabular}

Source : Calculations made with the samples

Tables 6 and 7 draw a comparison of predictability of default risk by Models 1 and 2 with a cut-off of 0.5 . The results suggest that predictability of Model 2 is better than that of Model 1 for both samples. As for Sample 1, Model 2 makes correct predictions for $97.59 \%$ of the cases (141 out of 144 surveyed companies) whereas Model 1 reaches 91.72\%. Similarly, as for Sample 2, the percentage recorded with Models 2 and 1 is $98.82 \%$ and $91.18 \%$ respectively.

From the above results, Model 2 is used to measure default risk and a new logistic regression function can be made with the coefficient $\left(\beta_{i}\right)$ as follows:

$$
p\left(Y_{i}=1\right)=\frac{\exp \left(-25.457-7.673 * \mathrm{LT}_{-} \mathrm{TS}+52.011 * \mathrm{TsNo} \mathrm{TT}\right)}{1+\exp \left(-25.457-7.673 * \mathrm{LT} \_\mathrm{TS}+52.011 * \mathrm{TsNo} \mathrm{TT}\right)}
$$

On the basis of this logistic regression function default risk of listed companies on stock markets can be quantified though the information on stock prices. The calculations 
with regard to this were made with 170 companies of Sample 2 in the years 2010-2011, and yet due to the scope of this paper,only few cases are presented in the following table.

Table 8: Calculations of Default Risk of Some Listed Companies on Stock Markets in 2010 and 2011

\begin{tabular}{|c|c|c|c|c|c|}
\hline \multirow{2}{*}{ Stock symbol } & \multicolumn{2}{|c|}{ Probability of default risk } & \multirow{2}{*}{ Stock symbol } & \multicolumn{2}{|c|}{ Probability of default risk } \\
\hline & 2010 & 2011 & & 2010 & 2011 \\
\hline AAA & 0.117 & 1 & CMT & 0 & 1 \\
\hline AAM & 0 & 0 & CSG & 0.001 & 0 \\
\hline ACC & 0 & 0 & CVT & 0 & 1 \\
\hline ALP & 0.998 & 0.995 & D2D & 0.549 & 1 \\
\hline AMV & 0 & 0.002 & DAG & 1 & 1 \\
\hline ANV & 0 & 0.999 & $\mathrm{DBC}$ & 0.985 & 1 \\
\hline APC & 0 & 0 & DCS & 0 & 0.069 \\
\hline APG & 0 & 0.086 & DHA & 0 & 0 \\
\hline ASM & 1 & 0.012 & DHG & 0 & 0 \\
\hline BAS & 1 & 1 & DHT & 1 & 0.98 \\
\hline BBS & 0 & 1 & DIG & 0 & 1 \\
\hline BCE & 0 & 0.999 & $\mathrm{DMC}$ & 0 & 0.001 \\
\hline BCI & 0.001 & 1 & DNY & 0.034 & 1 \\
\hline BDB & 0.931 & 1 & DPM & 0 & 0 \\
\hline BHS & 0.998 & 0.994 & DPR & 0 & 0 \\
\hline BHV & 1 & 1 & DRC & 0 & 1 \\
\hline $\mathrm{BKC}$ & 0 & 0.494 & DST & 0 & 0.997 \\
\hline CII & 0.186 & 1 & DTL & 0.98 & 0.998 \\
\hline CLG & 0.134 & 1 & DXG & 0.251 & 1 \\
\hline $\mathrm{CMG}$ & 0.992 & 1 & GMD & 0 & 0.745 \\
\hline
\end{tabular}

Source: Authors' calculations based on Model 2 


\section{CONCLUSION AND RECOMMENDATIONS}

\section{a. Conclusion:}

Measuring the default risk has always attracted the attention from many banking institutions, investors, and companies themselves and serves as a general indication of the status of a company. This paper has presented a method of combining the option approach and logistic regression analysis in measurement of default risk, and by such approach, found a correlation between market gearing ratio, expected return and default risk. Specifically, market gearing ratio has a positive relationship with the default risk, whereas expected return is negatively related to it, and these market variables, at the same time, allow a significant improvement in predictability of default risk as compared with independent variables which are financial indicators of a company.

By applying such combined method, a model measuring default risk of listed companies on Vietnamese stock markets has been developed using the input information extracted from stock prices.

\section{b. Recommendations:}

Through this research, it is highly recommended that banking institutions, investors, and companies choose this combined model as a tool to analyze, identify, and measure the risk of default whereby to adopt appropriate solutions for effectively controling the risk.

Furthermore, quantifying the risk and complying with market regulations are a general trend in risk management and supervision of banking activities in financially developed countries; hence, SBV policies should aim at encouraging and creating favorable conditions in order that commercial banks can conveniently make use of default risk measurement models by making use of information about stock prices of companies in the process of developing and improving their systems of internal credit rating.

At the government angle, this model can be applied by policy makers to update default probability of listed companies and catch up with degrees of insolvency risk among them. Dependent on that, the government will later make appropriate adjustments or exert substantial impact to avoid the chain effect of default which results in a brokendown credit system of the economy.

Apart from the achieved results, there remain quite a few limitations in the gathering of information about overdue debts due to the fact that the financial disclosure is not 
compulsory for listed companies while this is an early warning of bankruptcy of companies. This causes difficulties and inaccuracy for the evaluation of default risk with regard to the samples in this research. Currently, the information concerning the classification of enterprises' debts is updated at SBV Credit Information Center (CIC), yet individual investors still face difficulties in getting access to this information. Therefore, this research proposes that investors be allowed to access the information, thus making default risk assessment more transparent and helping investors make timely decisions

\section{Note}

[1] Moody's Corporation completed its acquisition of KMV in 2002 and changed its name into Moody's KMV.

[2] Basel II is a standard system designed to work on risk management and issued by the Basel Committee on Banking Supervision. Basel Committee consists of representatives from central banks and regulatory authorities of G-20 major economies

[3] Details of the indicators and how to calculate them used in this study are based on the research by Bùi Phúc Trung (2011)

\section{References}

Black, F. \& M. Sholes (1973), “The Pricing of Options and Corporate Liabilities”, Journal of Political Economy, Vol.81, pp.637-659.

Bùi Phúc Trung (2011), “Úng dụng phương pháp thống kê xây dựng mô hình xếp hạng tín dụng cho các doanh nghiệp nêm yết trên thị trường chứng khoán Việt Nam”, Phát triển kinh tế (March 2011).

Charitou, A. \& L. Trigeorgis (2004), "Explaining Bankruptcy Using Option Theory", University of Cyprus, working paper.

Crosbie, P. \& J. Bohn (2003), "Modelling Default Risk”, published by Moody’s KMV company.

Merton, R.C. (1974), “On the Pricing of Corporate Debt: The Risk Structure of Interest Rates", Journal of Finance, Vol.29 (2).

Papanastasopoulos, G. (2006), "Using Option Theory and Fundamentals to Assessing Default Risk of Listed Firms about Rating Migrations and Defaults", MPRA Paper No. 453.

Vassalou, M. \& Y. Xing (2004), "Default Risk in Equity Returns", Journal of Finance, Vol.59(2), pp.861-868. 